Article

\title{
EU-Mercosur Trade Agreement: Potential Impacts on Rural Livelihoods and Gender (with Focus on Bio-fuels Feedstock Expansion)
}

\section{Leonith Hinojosa}

Brooks World Poverty Institute and Impact Assessment Research Centre, School of Environment and Development, University of Manchester, Oxford Road, Manchester M13 9PL, UK;

E-Mail: Leonith.hinojosa@manchester.ac.uk; Tel.: +44-161-306-6430; Fax: +44-161-306-6428

Received: 9 October 2009 / Accepted: 24 November 2009 / Published: 26 November 2009

\begin{abstract}
The trade-sustainable impact assessment of the European Union-Mercosur trade agreement found that the economic impact of the trade liberalisation scenario could be positive in the agricultural sectors of Mercosur countries. However, it also found that the social and environmental impacts would be mixed and potentially detrimental. This paper addresses the likely effects on the livelihoods of vulnerable rural populations. It argues that the potential impacts can be analysed within a diversified livelihood strategies framework, which is expanded to include institutional and policy factors. It concludes that the negative expected impact responds to the highly uneven access to capital assets. On the other hand, the effects are not generalised to all Mercosur countries, nor to all regions in each of the member countries. Enhancing or mitigating measures refer to the importance of sequencing and regulation to improve disadvantaged groups' abilities to participate in trade-led agricultural intensification or industrialisation processes.
\end{abstract}

Keywords: sustainable impact assessment; livelihoods; bio-fuels; gender; Mercosur

\section{Introduction}

By the time this paper was finished in May 2009, the European Union-Mercosur trade agreement (EU-Mercosur Trade Agreement hereinafter) was still under negotiation. Mercosur country members include Brazil, Argentina, Uruguay and Paraguay and 25 of the 27 member countries of the European Union are also part of the negotiation (Bulgaria and Romania were not included in the trade SIA study). The agreement aims to establish sequential trade integration, based on the following principles: 
(i) a region-to-region approach, which constitutes the basis of discussions on all regulatory areas; (ii) a comprehensive and balanced agreement, where no sector should be excluded, while taking account of product sensitivities; (iii) an integrative approach, which means that the agreement should constitute a single undertaking, implemented by the parties as an indivisible whole. These principles follow the long standing tradition of the European Union to establish cultural, political and economic links with countries in Latin America, which ever since the 1960's have included a series of political and trade initiatives as well as cooperation agreements. Furthermore, the EU has sought to support the establishment of Mercosur. Indeed, in 1992, the European Commission signed an Inter-institutional Agreement with Mercosur to provide technical and institutional support to the fledging structures of Mercosur [1] and in December 1995 the two blocs started official trade negotiations. Furthermore, when Mercosur officially converted itself from a free trade area to a customs union, EU and Mercosur signed the EU-Mercosur Interregional Framework for Cooperation Agreement. The agreement was based on three pillars: political dialogue, cooperation and trade issues. Its objective was to create a framework for negotiations on an Interregional Association Agreement which should include full liberalization of trade in goods and services in conformity with WTO rules, enhanced form of co-operation and strengthened political dialogue. Negotiations for an EU-Mercosur Association Agreement were launched at the Rio Summit, in June 1999 and cover the full range of trade-related areas: trade in goods and services; sanitary and phytosanitary measures; the liberalization of capital movements; opening up government procurement markets for goods, services, and public works; competition policies; intellectual property rights; and dispute settlement [2,3].

To go along with the negotiation process, the European Commission commissioned a trade sustainable impact assessment (SIA), whose first phase included an overall SIA, as well as three sector-specific SIAs (in the agriculture, forestry and automotive sectors).

In that first phase, the trade SIA for the agriculture sector found that the economic impact of an EU-Mercosur trade liberalisation scenario would be positive in Mercosur countries. However, it also found that the social impacts would be mixed and potentially detrimental. Such an effect could accentuate the longstanding inequities observed in each one of the countries (for instance, measured by the Gini coefficient, the PNUD's 2009 Human Development Report registers that inequality in Brazil was $0.55,0.53$ in Paraguay, 0.50 in Argentina and 0.46 in Uruguay). As a result, the potential impact of trade liberalisation on rural livelihoods and gender was identified as an issue for detailed assessment in phase 2, in particular with regards to the expansion of bio-fuels feedstock production that would result from the EU-Mercosur trade liberalisation. Concerns were raised about the social and environmental impacts in Mercosur countries. The reports suggested that cross-linking indirect pressures could arise from reallocation of land between crop production, cattle grazing and forested areas whenever demand of agricultural products and bio-fuels increased [4]. In response to the concerns raised during the consultation process, the Impact Assessment Research Center (IARC), as part of the consortium which is doing the SIA, carried on with a particular desktop-based assessment to approximate the likely effects of the EU-Mercosur Trade Agreement on vulnerable rural groups and to identify some enhancing or mitigating measures.

This paper builds on a background paper prepared by the author for the Trade SIA EU-Mercosur, and argues that the likely impacts are mixed, because of the diversification that characterises the livelihood strategies of rural populations in Mercosur countries and the ways in which institutions and 
political capital condition their access to assets. Given those structural characteristics, trade liberalisation could induce concentration within the agriculture and forestry sectors and produce further diversification oriented towards wage labour. Incentives to accentuate asset concentration (particularly land), in order to produce economies of scale and to participate in the process of market expansion, could affect the most vulnerable groups if no mitigating measures are implemented to avoid asset dispossession and unfair labour-market practices. Although the study aims to cover most of the Mercosur countries' territories, the analysis of socio-environmental impacts accentuates the potential impact on the Amazon rainforest due to its significant frontier of expansion. Other regions with important biome such as the Brazilian Cerrado or the Paraguayan and Argentinean Chaco have received less attention either due to historical trends of very high level of conversion to agriculture induced by factors other than trade agreements or the lack of data.

The paper is organised in four sections. Section 1 summarises key findings of the SIA first phase which are relevant to analysis of the impacts on rural livelihoods and women, and presents a framework for understanding the linkages between trade policies and rural livelihoods. Section 2 overviews some structural factors that determine the characteristics of rural livelihoods in Mercosur countries, and shows the effects produced by agricultural intensification in past decades on the agricultural development of small farms and indigenous territories. Section 3 expands the rural livelihoods analysis to argue that non-agricultural livelihood strategies are also an essential part of the ways in which rural populations organise their economies. Section 4 evaluates the likely impacts of bio-fuel expansion on rural livelihoods and women. Section 5 concludes by identifying some policy implications to enhance the opportunities for disadvantaged rural populations to participate in favourable conditions in trade liberalisation scenarios.

\subsection{Departure Point: Identified Expected Effects of Trade Liberalisation on the Expansion of} Bio-Fuels Feedstock Production

The SIA Inception Report of the Mercosur-EU negotiations suggests that cross-linking indirect pressures will arise from the reallocation of land resources between crop production, cattle grazing and forested areas, once increased demand for agricultural products and bio-fuels is observed due to further trade liberalisation. Such a pressure would be observed mainly in Brazil and perhaps in Paraguay and Argentina.

In Brazil-currently (2008) the main bio-ethanol producer in the world-the immediate consequence of the bio-fuels industry expansion registered since the 1980s has been the development of large-scale sugar cane plantations, due to their efficiency and competitiveness in comparison to small-scale production [5]. According to some commentators [6,7], further expansion would bring negative consequences, such as deforestation, biodiversity loss, land use conversion and dispossession of smallholders' land; all these would have severe consequences for rising poverty. Unless mitigating and enhancing measures are implemented, the short-term positive effects on employment could also be offset in the long term due to the mechanisation processes induced by competition [2]. In the same way, the first phase SIA Final Report 2007 identifies potential negative impacts that include loss in some parts of the manufacturing sector, deterioration of decent work standards in some areas of the agricultural sector, and increased water pollution risks [8]. 
In spite of those forecasted results, the overall evaluation of a trade liberalisation scenario to the agriculture sector aggregate is positive for all Mercosur countries. Nevertheless, the above considerations have called for a more specific assessment and greater understanding of the issues underpinning the emergence of adverse effects. These are addressed in Section 2, based on the following framework constructed to analyse rural livelihoods.

\subsection{Analytical Framework}

Figure 1 represents the framework used in this paper to evaluate the potential impacts of a trade liberalisation scenario on the livelihoods of rural population [9]. The framework postulates that rural households-particularly the rural poor-present diversified livelihood strategies, which can be broadly classified into three categories: farm (i.e., agriculture), non-farm (all other activities carried on the rural area) and off-farm (e.g., temporary jobs carried on urban areas) economic activities. The formation and development of those strategies depend on a household's access to four types of assets or capitals: (i) natural capital, which includes all sorts of natural resources, such as land, water, forest, biodiversity; (ii) physical and financial capital, which includes man-made assets (infrastructure, monetary assets, machinery, and the like); (iii) human capital, which includes acquired capabilities (for instance, education and skills) and the assets that one has as a consequence of one's physical characteristics (for instance, health); (iv) social capital, which includes the assets that one has as a consequence of one's relationships (for instance, family and community ties, membership of organisations). These relationships in turn facilitate access to other resources Extensions to political capital and cultural capital have also been suggested to highlight the importance of politics in facilitating access to other forms of capitals, as well as to connect the institutional framework with such an access [10].

Figure 1. Framework to analyse the relationship between livelihoods and trade liberalisation in Mercosur countries.

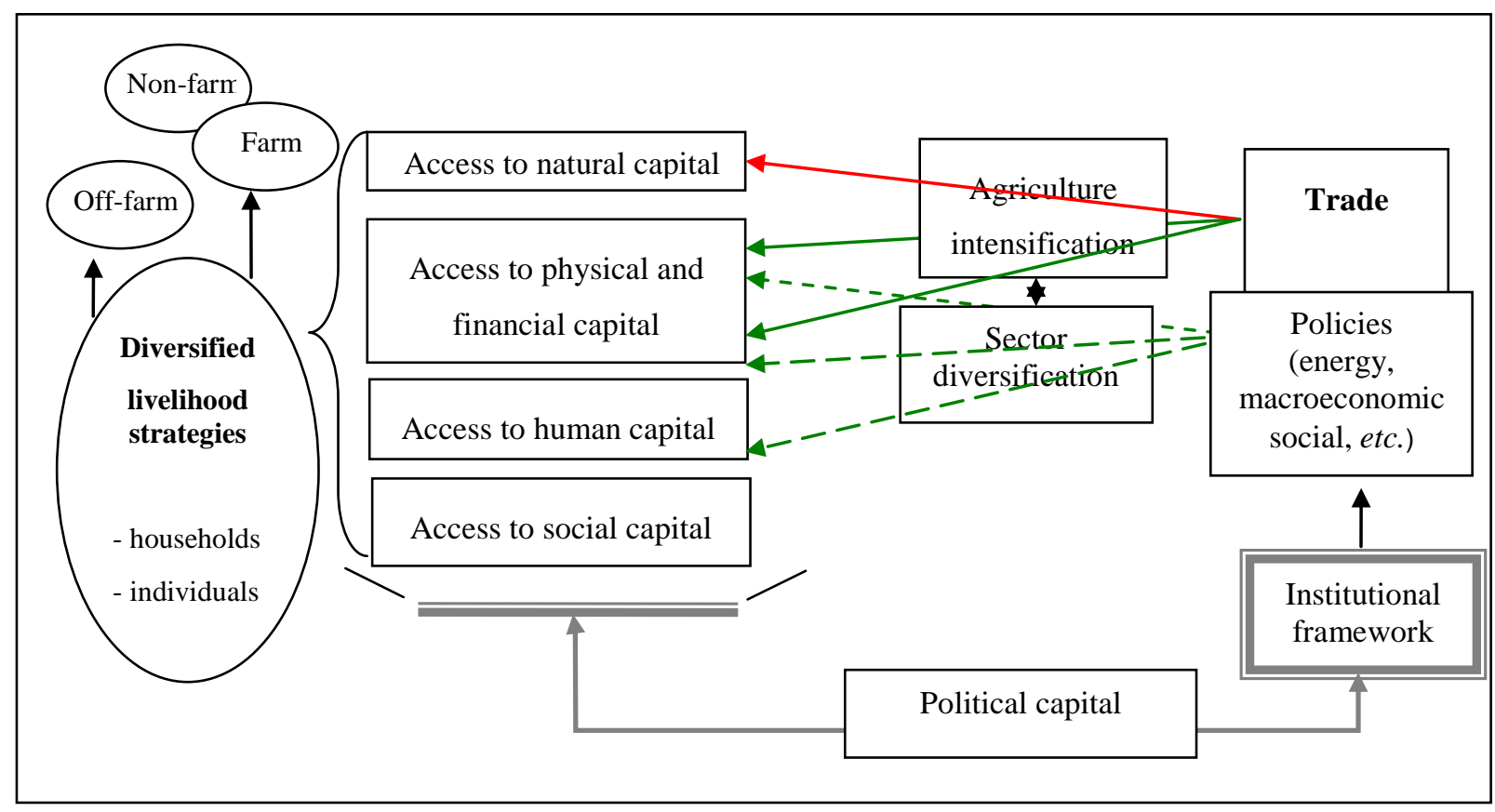


Access to capital-and consequently the livelihood strategies that a household can develop-is conditioned by the institutional framework implanted at local, national and regional scales, and includes both formal and informal institutions (laws, norms, customs and practices). The institutional framework determines specific economic and social policies too, which impact on the national (and regional) economic structures, by producing sector intensification and/or diversification. Trade policy-as one of the main components of economic policy-is both a result of the national development strategy and a factor that determines the level and sustainability of economic and social development. Thus, trade policy can reinforce underlying structures or, potentially, induce structural change.

It is in the process of sector restructuring induced by trade policies that the conditions in which households get access to capital are modified. The effects of trade policies on access to assets (represented by plain and dashed coloured arrows) mediate their impact on livelihood strategies. Whilst red arrows represent a negative effect, green arrows represent a positive effect. As already shown in the EU-Mercosur SIA first phase reports, those effects are expected to be mixed. It has also been shown that the effects of trade on particular groups of rural population are differentiated (for instance women, c.f. [11]). Special attention therefore has to be paid to heterogeneity among the rural population and even among the poor.

The likelihood that trade will positively impact on people's livelihoods (represented in Figure 1 by green plain arrows) depends on the extent to which general and complementary policy (macroeconomic, social, energy, sectoral and other ad hoc policies) minimise the risks of adverse effects on poor people and those groups most vulnerable to trade shocks [12]. In general terms, if trade liberalisation facilitates sector diversification, the expected effect of trade policies on livelihood strategies is assumed to be positive, due to new job opportunities, which facilitate the development of off-farm strategies. In the scenario where trade facilitates agriculture intensification, positive effects are expected if job opportunities are created (for instance, in new large plantations) or, alternatively, if the need for intensification induces small producers to associate. Both possibilities increase the chances for small producers to develop farm and off-farm strategies in rural areas. However, in this last scenario, a negative effect due to dispossession of land and other natural assets is also expected [13]. In that case, landlessness forces a faster diversification process and labour market development. How positive or negative that process is depends on the conditions in which the new landless are integrated into the labour market of the remaining economic sectors. Indeed, given that currently no Mercosur country has social protection programmes to cover unemployment, the landless have no other option than to develop some kind of off-farm livelihood strategies.

\section{Rural Livelihoods in Mercosur Countries}

Although Brazil, Argentina and Uruguay are among the countries with stronger economies in the Latin American region, poverty - and particularly rural poverty - is still widespread in all Mercosur countries, with the exception of Uruguay (see Table 1). According to some estimates, the incidence of rural poverty is particularly high in Brazil, with 41 percent of the rural population living under the poverty line. Within the rural population, the most vulnerable groups are women, young people and ethnic minorities, such as descendants of African origin in Brazil [14] and indigenous people in 
Paraguay. According to the International Fund for Agricultural Development (IFAD), in poor areas of Brazil, households headed by women account for 27 percent of the rural poor, and almost 40 percent of all children between the ages of 10 and 14 work to supplement family incomes [14].

In many ways, the poor in rural areas are more disadvantaged than the poor from urban areas, due to insufficient infrastructure, difficult access to public services, and limited access to technology. This reduces opportunities for the rural population to supplement farming incomes through salaried labour and it also makes it more difficult to develop small-scale non-farm and off-farm activities. Given these constraints, much discussion about the likely effects of large-scale investments and trade-led development strategies is centred on the eventual competition that trade liberalisation would produce on land-and water-once market incentives (e.g., price increases, larger demand and lower production costs) produce opportunities for large-scale investments (and/or companies) to settle down in rural areas, which compete with small farmers and/or community groups (whether indigenous people or peasant communities).

Table 1. Rural population, land availability and poverty in Mercosur countries.

\begin{tabular}{|c|c|c|c|c|c|c|c|}
\hline Country & $\begin{array}{l}\text { Rural } \\
\text { Pop. } \\
2006 \\
(\%)\end{array}$ & $\begin{array}{l}\text { Rural Pop. } \\
\text { growth } \\
\text { (annual \%) }\end{array}$ & $\begin{array}{l}\text { Agricultural } \\
\text { land }(\% \text { of land } \\
\text { area } 2003\end{array}$ & $\begin{array}{l}\text { Arable } \\
\text { land }(\% \text { of } \\
\text { land area } \\
2003\end{array}$ & $\begin{array}{l}\text { Agricultural land } \\
\text { (Ha. per person } \\
\text { rural pop. 2003) }\end{array}$ & $\begin{array}{l}\text { Arable land } \\
\text { (Ha. Per } \\
\text { person rural } \\
\text { pop. 2003) }\end{array}$ & $\begin{array}{l}\text { Poverty gap } \\
\text { at } \$ 2 \text { a day } \\
(\text { PPP 2003*) }\end{array}$ \\
\hline Argentina & 9.7 & -1.6 & 47.0 & 10.2 & 33.0 & 7.16 & 8.4 \\
\hline Brazil & 15.3 & -1.0 & 31.2 & 7.0 & 8.6 & 1.91 & 8.3 \\
\hline Paraguay & 40.9 & 1.6 & 62.5 & 7.7 & 10.2 & 1.25 & 13.8 \\
\hline Uruguay & 7.9 & -2.6 & 85.4 & 7.8 & 54.7 & 5.01 & 1.6 \\
\hline Venezuela & 6.3 & -0.3 & 24.5 & 2.9 & 11.2 & 1.35 & 19.2 \\
\hline
\end{tabular}

Notes: (*) PPP is power purchasing parity.; n.a. = not available; Pop.= population; Source: World Bank [66].

As shown in Table 1, even though countries such as Argentina, Paraguay and Uruguay are well endowed with agricultural land, the proportion of arable land (that is, what is really usable for cropping purposes) ranges between 2.9 and 10.2 percent of total land extension. With that amount of land, the countries most endowed with agricultural and arable land are Argentina and Uruguay, and Brazil is the less advantaged. That implies that if the rural population is mostly dedicated to agricultural activities, a rural household would have between 40 and 60 hectares (ha) of agricultural land in countries such as Brazil, Paraguay and Venezuela, 165 ha in Argentina and 273 ha in Uruguay. Considering arable land only, the same households would have 6 to 10 ha in Paraguay, Venezuela and Brazil, and 25 and 36 ha in Uruguay and Argentina.

However, averages do not reveal distribution and, even though these numbers suggest relative land availability, in practice it is also fair to say that land, while available — and even abundant—-for some, is scarce for others. Over time, land concentration, appropriation and expropriation have become general features in almost all Mercosur countries. Such a process of land concentration has developed in a context where increased market liberalisation has produced incentives for scale economies and weakened states were not sufficiently able to regulate formal and informal market practices and to protect small landholders and indigenous groups. Table 2 illustrates this suggestion for the Brazilian case. In Brazil, about 95 percent of livestock farmers are land owners. Fewer than 10 percent of farms 
hold two-thirds of the herd. In that context beef production is developed in farms over 100 ha, which involve 82 percent of livestock. Milk production, by contrast, has a large number of livestock in farms of less than 50 ha, which contribute 39 percent of national production [15]. This implies that most of the agricultural land shown in Table 1 is the private property of large farmers.

Table 2. Brazil: land tenure in cattle enterprises.

\begin{tabular}{ccc}
\hline Percentage of the herd & Farm size & Percentage of farms \\
\hline 27.19 & $>1000$ ha & 0.94 \\
38.77 & $100-1000$ ha & 9.35 \\
24.0 & $10-100$ ha & 34.06 \\
8.25 & $<10$ ha & 43.96 \\
\hline
\end{tabular}

Source: FAO, Brazil, country profile [16].

In Paraguay, concentration has been favourable to foreign investors (mainly Brazilian and Argentinian) who have developed extensive cattle ranges and soy plantations in The Chaco region [17]. In Uruguay, farms over 10 ha represent 99.6 percent of the total area, and many smaller farms which proved to be economically non-profitable have been abandoned in the last three decades [18]. In Venezuela 1.5 percent of farm units occupy 57.9 percent of the agricultural area [19]. Argentina is a land-rich country, with average farm size of 518 ha, ranging between 74 ha in Misiones and 21,012 in Santa Cruz. A few holdings exceed a million hectares in Patagonia or the dry west, or 200,000 ha in the humid Pampas or Campos or Chaco. Only 20 percent of this area is cultivated [20].

In those conditions, should the EU-Mercosur Trade Agreement foster growth in the agriculture sector via expansion of investment in cattle grazing and bio-fuels feedstock production, it would necessarily imply a continuation of the process of land concentration-and, perhaps, land dispossession - to allow economies of scale.

As the EU-Mercosur SIA in the forestry sector suggests, trade liberalisation can also imply the expansion of agricultural area at the expense of forest reduction-a point particularly sensitive in the Amazon region, due to the additional costs of biodiversity loss, which in turn threatens the livelihoods of indigenous people, some of whom (the non-contacted groups) are not even counted in official statistics. Indeed, change in primary/modified natural forest cover between 1990 and 2005 was -8.3 percent in Brazil, -12.7 percent in Paraguay and -7.8 percent in Argentina. Uruguay increased its forest cover by 5.1 percent, much of it for commercial agriculture which may also have an impact on biodiversity loss. [21].

As in the case of cattle ranches, production of sugar cane (the main ethanol feedstock) is dominated by large estates in Brazil [5]. Areas of expansion with greater future potential are those that combine three conditions: soil quality, pluviometric precipitation and logistics (particularly, infrastructure to deliver the production of ethanol to consumer centres or to harbours for export). Currently, those areas are located in the Brazilian 'Triangulo Mineiro' (Minas Gerais State), northwest of Sao Paulo State, Mato Grosso do Sur State, Goias State and the north of the Espirito Santo State [22]. In other areas of the country, expansion would require big investments in irrigation, which eventually could be made due to the lower land cost. Most expansion on existing sugar cane areas is taking place on degraded and pasture lands. According to Lora, quoted in [22], the expansion of sugar cane production has 
replaced pasturelands and small farms of varied crops. Plantations for sugar and ethanol production have expanded mainly into areas once used for cattle grazing, as cattle are mainly confined to cattle ranching and in a small scale to new pastureland (which may include cleared rainforest).

\section{The Threat for Indigenous Territories}

Part of the concern about large agriculture investments, whether in bio-fuel feedstock or cattle ranges, is related to their effects on indigenous people. Forest clearing and further expansion of the agricultural frontier into the Brazilian Amazon or the Gran Chaco region (a territory involving Paraguay, Uruguay and Argentina) has been reckoned to reduce the natural resources-land and biodiversity - on which the livelihoods of indigenous people depend. As far as restrictions to expand the agricultural frontier apply — at least officially — the implication of increasing sugar cane production would be either an irreversible conversion of pristine ecosystems (together with the consequent loss of ecosystem functions) or dispossession of the land possessed by small landholders or indigenous groups. In such a context, advocacy groups have largely claimed that such a dispossession process is conducted through legal and illegal mechanisms (see, for instance, IPS' articles covering land conflicts [23]).

As an illustration of potential conflicts between bio-fuels feedstock fields and indigenous territories, Table 3 shows the magnitude of indigenous population by regions in Brazil, the economic sectors which concentrate most of the economically active population, the already registered land conflicts in each region and a forecast for sugar cane field expansion. The following points are noteworthy: firstly, the West Centre is a critical region, where the proportion of rural indigenous people is higher, there have been land conflicts and the prospects for bio-fuels feedstock are relatively high. In other regions the potential problem of territorial overlapping seems to be less critical. Secondly, the effects of restrictive regulation for agricultural frontier expansion can be different in the short from in the long run. Given the relatively low cattle density in the Brazilian pasturelands ( $100 \mathrm{head} / \mathrm{km}^{2}$ compared to higher averages (120-140) in developed countries), it is possible that in the short run, range-cattle intensification may not overstress pressure on indigenous lands. In the long run, a combined effect of substitution of cattle ranges by sugar cane fields, with the relocation of high-yield cattle ranges, would necessarily imply an inevitable displacement — and a potential elimination — of lower-yield small-scale cattle grazing and agriculture. Thirdly, land conflicts originated by processes of dispossession - that is, by the accumulation of large farmers at the expense of small or indigenous farmers-create an unsuitable scenario for new investments and political unrest.

Having said that, it is also fitting to remark that, in recent Brazilian history, the fight for land is not only about the big against the small landowners. Processes of conversion from small-scale to large-scale agriculture (both for soybean and cattle production) have led to land concentration and the displacement of small farmers, who either have migrated into urban areas or moved into forest areas $[24,25]$. But, conflicts have also been produced between small farmers (the colonisers) and indigenous communities. As shown by Schmink and Wood, deforestation, settlement patterns, and conflicts in rural areas have been outcomes of the competition for resources among ranchers, peasants, loggers, indigenous peoples, goldminers, rubber farmers, bureaucrats, and large investors [26]. When displacement has led to urbanisation, the new "urban" political groups have put pressure 
(via large-scale occupation) on governments to expand urban settlements in forest areas, exacerbating deforestation rates [27].

Table 3. Expansion of bio-fuels feedstock and indigenous territories in Brazil.

\begin{tabular}{|c|c|c|c|c|c|c|}
\hline Regions & $\begin{array}{l}\text { Indigenous } \\
\text { Population } \\
(2000) \text { a/ } \\
\end{array}$ & $\begin{array}{l}\text { Indigenous } \\
\text { population in } \\
\text { rural area b/ }\end{array}$ & $\begin{array}{l}\text { Rural } \\
\text { population } \\
\text { c/ }\end{array}$ & $\begin{array}{l}\text { Population economically } \\
\text { active in main economic } \\
\text { activities in the region } \mathrm{d} /\end{array}$ & $\begin{array}{l}\text { Sugar cane } \\
\text { expansion } \\
\text { forecast }\end{array}$ & $\begin{array}{l}\text { Land conflict- } \\
\text { related deaths } \\
\text { e/ }\end{array}$ \\
\hline Brazil & $\begin{array}{l}734,127 \\
(0.4 \%)\end{array}$ & $\begin{array}{l}350,829 \\
(1.1 \%)\end{array}$ & $\begin{array}{l}31,845,211 \\
(18.8 \%)\end{array}$ & $\begin{array}{l}\text { Agric } 17.9 \% \mathrm{~W} \& \mathrm{R} \\
\text { trade-Re.Veh. } 16.6 \% \\
\text { Manufact. } 13.3 \%\end{array}$ & n.r. & $777 \mathrm{f} /$ \\
\hline North & $\begin{array}{l}213,443 \\
(1.7 \%) \\
\end{array}$ & $\begin{array}{l}167,140 \\
(4.3 \%)\end{array}$ & $\begin{array}{l}3,886,339 \\
(30.1 \%)\end{array}$ & $\begin{array}{l}\text { Agric. } 17.9 \% \mathrm{~W} \& \mathrm{R} \\
\text { trade-Re.Veh. } 16.6 \%\end{array}$ & n.r. & 584 \\
\hline $\begin{array}{l}\text { North- } \\
\text { East }\end{array}$ & $\begin{array}{l}170,389 \\
(0.4 \%)\end{array}$ & $\begin{array}{l}64,661 \\
(0.4 \%)\end{array}$ & $\begin{array}{l}14,766,286 \\
(30.9 \%)\end{array}$ & $\begin{array}{l}\text { Agric. } 30.4 \% \text { W\&R } \\
\text { trade-Re.Veh. } 15.0 \%\end{array}$ & n.r. & 105 \\
\hline $\begin{array}{l}\text { South- } \\
\text { East }\end{array}$ & $\begin{array}{l}161,189 \\
(0.2 \%)\end{array}$ & $\begin{array}{l}20,544 \\
(0.3 \%)\end{array}$ & $\begin{array}{l}6,863,217 \\
(9.5 \%)\end{array}$ & $\begin{array}{l}\text { W\&R trade-Re.Veh. } \\
\text { 17.5\% Manufact. } 15.6 \% \\
\text { Agric. } 9.6 \%\end{array}$ & $\begin{array}{l}\text { Sao Paulo } \\
35 \% \text { Minas } \\
\text { Gerais } 18 \% \\
\text { Rio de } \\
\text { Janeiro } 1 \%\end{array}$ & n.r. \\
\hline South & $\begin{array}{l}84,747 \\
(0.3 \%)\end{array}$ & $\begin{array}{l}32,500 \\
(0.7 \%)\end{array}$ & $\begin{array}{l}4,785,617 \\
(19.1 \%)\end{array}$ & $\begin{array}{l}\text { Agric. } 19.7 \% \text { Manufact. } \\
\text { 17.3\% W\&R trade-Re. } \\
\text { Veh. } 16.2 \%\end{array}$ & Parana 4\% & n.r. \\
\hline $\begin{array}{l}\text { Centre- } \\
\text { West }\end{array}$ & $\begin{array}{l}104,360 \\
(0.9 \%)\end{array}$ & $\begin{array}{l}65,985 \\
(4.3 \%)\end{array}$ & $\begin{array}{l}1,543,752 \\
(13.3 \%)\end{array}$ & $\begin{array}{l}\text { W\&R trade-Re.Veh. } \\
\text { 17.9\% Manufact. } 15.1 \% \\
\text { Agric. } 9.9 \%\end{array}$ & $\begin{array}{l}\text { Goias } 10 \% \\
\text { Mato Gross } \\
\text { do Sul } 9 \%\end{array}$ & 88 \\
\hline
\end{tabular}

Source: Population is census data. Other columns are based on [22].

Notes: Numbers in parentheses are percentages of each category's corresponding national or regional entire population: $a /$ percentage of entire population; $b /$ percentage of rural population; $\mathrm{c} /$ percentage of entire population. $\mathrm{d} /$ Percentage of population economically active ( $>10$ years old) per economic sector. Agric.: Agriculture and hunting; W\&R trade-Re.Veh.: Wholesale and retail trade, repair of motor vehicles; Manufact.: Manufacturing. e/ Land conflict-related deaths in the Legal Brazilian Amazon, 1985-1999. f/ Amazon region only. n.r.: no plantations/conflicts registered.

In addition, infrastructure developmental projects have had an unexpected effect on land distribution and appropriation. Conflicts over land in the Amazon region have increased in those areas where agricultural land has been made accessible by development efforts, particularly road construction. New immigrants, small farmers and large ranchers fight for increasing access to those lands which, if unattractive before, now that they are closer to markets are worth fighting for.

These problems are not confined to Brazil only. Conflicts over land (and associated conflicts over water) have also been observed in other Mercosur countries. That has given place to the formation of ad hoc community organisations and advocacy networks which, over time, have strengthened their voice and positioned as significant political contestants or allies. That has been the case of the Movimento dos Trabalhadores Rurais sem Terra (MST) and the Movimiento de Mulheres Camponesas in Brazil, the Movimiento Campesino Paraguayo (MCP) and the Organizacion de Lucha por la Tierra 
(OLT) in Paraguay, the Coordinadora de campesinos, indígenas y trabajadores rurales (COCITRA) and other similar regional organisations in Argentina. Many of these organisations work nowadays in collaboration with each other. They also work together with the NGO sector, which provides logistic, financial and political support. Both have produced global civil society networks, which in the last decade have confronted trade liberalisation negotiation agreements as well as other forms of international arrangement that threaten the viability of small agriculture (for instance, networks such as The Via Campesina and the International Land Coalition). These organisations, and the social movements they produce, need to be taken into consideration, due to their role in shaping government policies and the response from large investors. Despite the criticism about the weaknesses of global civil society to ensure effective participation mechanisms, in particular in international forums [28], it is worth to acknowledge that international decision-making spaces are more and more influenced by civil society alliances and coalitions. These groups are crossing political and institutional borders to contest and devise arrangements intended to make international agreements between states-in particular, trade agreements - more favourable to disadvantaged local population [29].

The evidence provided above inclines the evaluation towards a negative balance that liberalisation of trade in the agriculture and forestry sectors would produce for the more vulnerable groups in rural areas of Mercosur countries. However, the agricultural component of rural livelihoods gives only part of the story. Agricultural livelihood strategies are-indeed-essential, but they are only part of the set of livelihood strategies. Therefore, a full assessment of the likely effects of the EU-Mercosur TA on livelihoods requires us also to look at the likely effects on other non-agricultural strategies on which rural households rely. This point is addressed in the following section.

\section{Beyond the Agricultural View of Rural Livelihoods}

Reference has already been made to the likelihood of both positive and negative social impacts of trade liberalisation on rural poverty and livelihoods, as it was presented by FDLC during the consultation process of the Trade SIA EU-Mercosur [30]. This section aims to provide insights into various factors that explain such mixed effects, and then identifies some of the elements that need to be taken into account in order to mitigate or enhance forecasted impacts. The argument presented in this section hinges around a discussion of: the full composition of households' livelihood strategies, the spatial (rural-urban) linkages involved in those strategies and the implications in terms of women's welfare and gender relationships.

\subsection{Diversified Livelihoods}

Studies on rural livelihoods in Latin America show that individuals and households from rural areas develop diversified strategies that combine farm, non-farm and off-farm activities (among them: agriculture, cattle grazing, food processing, hand crafting, petty commerce, wage labour in agriculture, as well as in temporary or even permanent urban employment, and so on) [31-33].

That being the case, it is noteworthy that the composition of livelihood strategies (that is, the weight of each one of the economic activities on the household's output and income, as well as on individuals' use of time) changes over time. In the recent history of Mercosur countries, part of that change has 
followed general trends of migration linked to urbanisation and, in cases such as Brazil and Argentina, to industrialisation processes which have induced forms of 'natural' and 'voluntary' change. However, in recent decades farm mechanisation, technological change and diversification in production have contributed to loss of rural employment, pushed people to migration and produced 'unwanted' and 'tense' change. The expansion of bio-fuels feedstock production has somehow been more associated with the latter process. It is not clear though whether the social drawbacks of such a change are compensated by the economic payoffs it may have produced and, therefore, whether a national strategy of development based on bio-energy has the scope to include rural development and can obtain people's acceptance and support. (This point is addressed in more detail in Section 4.)

Diversified livelihoods in the rural area mean also that many of the economic units (either formal or informal enterprises) are formed under the initiative and labour participation of the household members. In the case of Brazil, 100 percent of agricultural units (estabelecimentos) reported kinship links between the 'employer' (producer) and 'employees' (labourers), and only 13.9 percent of hired labour had no kinship relationships with the head of the economic unit (5.9 percent in the South East and 20.6 in the West Centre, both important regions in terms of bio-fuels feedstock production). This fact has implications for the regulatory measures to be implemented in the EU-Mercosur TA. Whilst the productive potential of family networks has been demonstrated to be beneficial for developing entrepreneurship at the small and medium scale - particularly in the informal sector-studies also show that informality and kinship relationships have been used to reproduce unfair labour exploitation mechanisms - particularly damaging for women and children.

Diversified livelihoods at the household level produce dynamic effects on urbanisation and deforestation, but (in time) they also produce incentives for specialisation and more productive use of available assets at the level of the individual. The combination of livelihood strategies along rural and urban areas implies that the rural-urban divide becomes a narrow line in regions where both agriculture and non-agricultural activities are profitable, whether in terms of business or households' food security.

Movements between rural and urban spaces are not in one direction only. In the same way as the rural population moves temporarily into urban areas looking for wage labour, a substantial number of urban dwellers are employed as wage labour in rural areas. In the Brazilian Amazon, despite the rapid pace of urbanisation, urban dwellers are employed in the rural areas tied to agro-extractive production systems.

It is within this two-direction (rural-urban and urban-rural) scenario that alternative understandings of resource allocation and land conflicts may be needed, in order to foresee the implications of trade and macroeconomic policies that provide incentives for expanding the agricultural frontier. The dynamics produced in the urban-rural space and the implications it has for vulnerable population (both from rural and urban areas-increasingly the same households spread in both areas) require a balanced view of the costs and benefits of further development of the bio-fuels and any other natural resource-based industries. In the same vein, the trade-offs involved between short-run effects and longrun impacts need to be interpreted in a framework that includes the various dimensions in which "rural" households develop their livelihood strategies. 


\subsection{Rural-Urban Migration Movements in Mercosur Countries}

Although with some differences of degree, all Mercosur countries follow a similar pattern of increasing urbanisation which, as in the rest of Latin America, finds roots in the pro-urban bias of the import substitution industrialisation model implemented up to the 1980s. The new development strategy implemented afterwards-based on higher trade integration and the exploitation of natural resources, which increased productive buoyancy in rural areas-has not reversed that effect. The agricultural revival based on large-scale farms and forestry has pushed out traditional farming and mainly produced highly seasonal labour demand, often met by urban workers from faraway cities. As a net result, there are no signs of counter-urbanisation triggered by productive causes and any return to the countryside seems not to represent a return to agriculture [34]. In contrast, it has also been shown that negative environmental conditions and landlessness consistently increase in-country out-migration but it does not international migration; land ownership and international migration seem to be positively correlated [35-67].

Overall, the relationship between internal migration and the level of subnational development is positive. However, patterns of migration in the Amazon region of Brazil, the extreme South of Argentina and Eastern Paraguay show that the abundance of natural resources and expectations of fast profit have superseded more traditional pull factors such as average wages and living conditions [34]. The prospects of job creation and individual and regional advancement of these regions, and the respective migratory dynamics, are closely linked to the world economy. This means that further trade integration can create opportunities for more balanced regional growth, but it also introduces external factors of vulnerability, and sources of emigration in case of external recession.

Emigration effects on poverty reduction or chronic poverty are not conclusive. In depressed areas, such as the North West of Argentina and the North East of Brazil, migration systematically has an adverse effect on the age structure, increases demographic dependence and tends to erode the limited human capital by reducing the average level of schooling. In those conditions, emigration may provide an exit for those migrating, but turns the rural area into a territorial poverty trap [34]. If the overall forecasted effects of the EU-Mercosur Trade Agreement are realised-that is, growth and internal redistribution in the agriculture and forestry sectors and a decrease in manufacturing production-areas which have little agricultural potential are likely to decline and expel population. Even in areas where agriculture can be developed based on agro-industrial centre models, segmentation among producers is likely to push population to urban areas. As it has been observed in the 1990s in the Argentinean Pampa [36], workers in the agricultural labour market are predominately urban-most of them permanent rural migrants. According to some commentators, c.f. [35], these rural migrants are the major drivers behind deforestation. The paradigmatic case of Rondonia in Brazil, where agrarian colonisation was accompanied by increased urbanisation [36], shows the strong trend towards urban settlements, even if employment continues to be rural.

It can also be expected that the adverse effects on the Mercosur countries' manufacturing sectors will impact on the changing urban system which, since the 1980s, has favoured the development of medium-sized cities. Industrial promotion, the mining industry or tourism has underlain the greater dynamism of middle-sized cities in Argentina [37]. Yet, the net impact on wellbeing that those effects have is also dependent on the characteristics of migrants and their households (age, education level, 
health status). For instance, the migration flows from North to South in Brazil show that migration relapses have been higher in the South than in the North [38].

Finally, as in the case of other Amazonian regions where the expansion of non-timber exploitations has improved rural livelihoods, the case of the bio-fuels economy in rural regions of Mercosur countries shows that bio-fuel-based employment and income can be critically important for poor and marginalised households in urban and suburban environments. When analysing the livelihood strategies prevalent in a broader understanding of diversified livelihoods, the rural-urban dichotomy becomes blurry. Rather than a rural-urban divide, it is the rural-urban nexus underlying these strategies that explains their flexibility, adaptability and viability.

\subsection{Implications for Labour Standards}

Controversy over the impacts of large agricultural investments on labour conditions in rural Brazil is high. Whilst activists' voices have been heard since the 1990s denouncing rural workers' entrapment and unacceptable labour conditions [39], some contributors suggest that some forms of private investment have positively impacted labour conditions. For instance, private colonisation cooperatives would have successfully secured land titles, setting the stage for subsequent commercial agricultural developments with labour standards improvements, c.f. [40]. The argument here is that, wherever labour relations and land access develop in contexts of high transaction costs and risk, 'pre-capitalist labour relations' are more likely to create opportunities for lowering labour conditions. Thus, a more articulated and formal market economy, where institutions are more stable, is more likely to produce better working conditions.

Preoccupation with low working conditions is not exclusive to rural environments. Conditions of labour resistance and control in dynamic and highly urbanised agricultural regions may explain the use in such regions by employers of entrapped workers from distant regions - a situation well documented by Chase (1999) in Brazil. Furthermore, worker rights violations in urban areas would also characterise many of the Mercosur countries [41]. Indeed, studies from the ILO done in Brazil in the construction sector, which absorbs significant numbers of rural workers (in temporary or permanent jobs and in infrastructure-based social policy programmes) show that decent work remains a marginal concept. Nevertheless, in construction, as in other sectors, there seems to be scope for improvement at local levels [42]. It may also be the case that a combination of labour regulation given at central level, and added certification mechanisms, would be useful to induce private businesses to improve their labour standards in order to increase their market share.

\section{Likely Impacts of the EU-Mercosur TA on Livelihoods and Gender-with Focus on the Effects of Bio-fuels Expansion}

At the macro-scale, as a recent study from ECLAC and GTZ [65] concludes, an impact assessment of the expansion of bio-fuels in the Latin American region has to deal with marked differences between countries in regard to their availability of natural resources, energy requirements, food sufficiency and their previous experience, technological development and the logistics already in place 
for the bio-fuels industry. Consequently, no overall generalisation across countries, and even within countries, is desirable.

For countries with considerable experience in the production of bio-fuels (only Brazil in Mercosur), a combined development of the bio-ethanol value chain with the purposeful substitution of oil by biofuels, both to satisfy domestic energy requirements and to meet foreign demand, offers positive prospects of expansion (see Table 4 and the SIA report for the Forestry sector, pp. 84-88). Expected impacts on the agriculture sector could be positive if - as is postulated in the USA's bio-fuels agenda - the expansion of bio-fuels leads to new practices which reduce the effects of climate change and promote the use of renewable energy.

Table 4. Policy goals for the expansion of bio-fuels.

\begin{tabular}{lll}
\hline Country & Bio-ethanol & Bio-diesel \\
\hline Argentina & $5 \%$ of final product by 2010 & $5 \%$ of final product by 2010 \\
Brazil & $22 \%$ from 2001 & $2 \%$ by 2008 and 5\% from 2013 to 20\% by 2020 \\
Paraguay & $18 \%$ as minimum amount & $1 \%$ in $2007,3 \%$ in $2008,5 \%$ in 2009 \\
\hline
\end{tabular}

Source: ECLAC and GTZ, based on official data, [43].

Considering those prospects of expansion and the foreign demand from other world regions, the concern raised by development practitioners and some academic commentators is about the impacts of such an expansion on rural populations and people living in poverty. For instance, forecasted imports from the USA, EU25 and China in 2020 show that they would reach 50 percent of their domestic demand of biodiesel; from India 30 percent; and from Japan 90 percent [65].

At the micro-scale, if the argument presented in the section above about the strength of diversified livelihood strategies and the narrow urban-rural divide is accepted, the likely impacts of a trade agreement - and specifically of the expansion of bio-fuels - ought to be assessed by looking at the direct and indirect effects on both the agricultural and non-agricultural strategies that households develop. The direct effects regard the open opportunities or imposed constraints on rural households, in their access to natural resources (mainly land and water) on which agricultural livelihood strategies rely. In parallel, direct effects can also be expected on employment in the bio-fuel industry. The indirect effects regard the induced effects on change in livelihood strategies, by facilitating or constraining access to other forms of assets (human, financial and physical assets) which enable the development of new forms of livelihood strategies.

\subsection{Expansion of Bio-Fuels and Food Security}

The opposition between bio-fuels and food is generally portrayed in terms of the competition it means for alternative land allocation, given the overall land availability. In addition, the rapid growth in first-generation liquid bio-fuel production has raised concern about the likely negative effects on food prices, which particularly affect poor people, who spend a large share of their income on food [44].

In regard to suspected restrictions imposed by land availability, food security should not be a problem in Mercosur countries, with the exception of Venezuela (see Table 5). However, land 
availability is not a sufficient condition to ensure food security. Despite the potential of natural resources for food production and the high percentage of food exports registered in the decade, the percentage of undernourished population (notably in Venezuela and Paraguay, and to a lesser extent in Brazil) is also high. Furthermore, during the period between 1990-1992 and 2001-2003, in countries such as Venezuela, Argentina and Paraguay, indicators of malnutrition worsened with reference to established World Food Summit goals. This fact warns us about the abilities of Mercosur countries to produce the conditions (political and institutional) which, at the same time, both ensure food security and energy supply for their own populations, as well as support export-oriented energy policies.

Table 5. Land availability and food security in Mercosur countries.

\begin{tabular}{lcccc}
\hline Country & $\begin{array}{l}\text { Area Required } \\
\text { for food as \% of } \\
\text { arable land }\end{array}$ & $\begin{array}{l}\text { Area required for } \\
\text { bio-fuels as \% of } \\
\text { arable land a/ }\end{array}$ & $\begin{array}{l}\text { Food exports } \\
\text { (\% of exports) } \\
(\mathbf{2 0 0 4 )}\end{array}$ & $\begin{array}{l}\text { Percentage of } \\
\text { undernourished } \\
\text { population }\end{array}$ \\
\hline Argentina & 28 & 8 & $>40$ & $<5$ \\
Brazil & 65 & 11 & $20-40$ & $5-10$ \\
Paraguay & 42 & 3 & $>40$ & $10-20$ \\
Uruguay & 51 & 12 & $>40$ & $<5$ \\
Venezuela & 209 & 24 & $0-20$ & $10-20$ \\
\hline
\end{tabular}

Note: a/ Estimates based on each country's expected demand at 2020 (improvements in bio-fuel crops included). Statistics do not include additional land surface needed to satisfy foreign demand. Sources: Based on [65] and [43].

Consequently, although the overall macro effects of biofuels expansion seem to offer potential benefits for most of Mercosur countries, it can also be expected that human groups and places will be affected in different ways. For instance, in Brazil, the North-East region is the poorest and least developed part of the country. The region contains the single largest rural poverty concentration in Latin America. Landless and smallholder farmers in the semi-arid zone are critically affected by rural poverty. In this region, adverse climatic conditions and limited access to public services have led to the migration of large numbers of people to urban areas, mainly to big cities in South-Eastern Brazil [15]. Studies demonstrate that those migrants are better off now in their new location than before. In addition, the incorporation of such a labour force into manufacturing and services has increased demand and output in the Southern region. Notwithstanding, positive effects of migration may not benefit in the same way or magnitude to all household members. Particular gender roles, ideologies and identities, and household divisions of labour are historically and contextually produced and transformed in migratory processes [45].

\subsection{Impacts on Sustainable Livelihoods}

From an agricultural view of rural livelihoods, one of the main causes of poverty in rural Brazil is the extreme inequality of land tenure. This, although less severe, is also the case in Paraguay and Venezuela. In a scenario where commercial agriculture expands and further concentration is inevitable, due to required economies of scale, small landholders keep developing subsistence farming (as long as they can compete and fight for their land rights) [46,47], pushing further into the forest in search of 
new land to settle. They increasingly work part-time in order to supplement their livelihoods, or move to the city in search of permanent employment [48]. A desirable successful passage from agriculture to more profitable activities is limited by their reduced access to financial capital and low access to formal education and non-agricultural skills training. This, combined with limited access to basic infrastructure, reduces the capabilities of individuals - and particularly women - for technology appropriation and higher integration into markets.

An alternative scenario of land and/or product agglomeration that has facilitated economies of scale and produced mechanisms of equitable growth has emphasised the development of cooperatives, producer associations and the like. Indeed, there is significant experience of cooperative models in Latin America. In Brazil, it has been estimated that nearly 40 percent of agricultural output is produced by its 1,406 agricultural cooperatives [49]. In the bio-ethanol industry there are established sugar cane cooperatives as well as other agricultural cooperatives that produce on degraded sugar cane plantation land [50]. In Paraguay soybean cooperatives located near Paraguay's border with Brazil have taken advantage of the soy boom in the last decade and liaised with multinational agribusiness firms. Not all cooperatives, however, have always been successful at achieving competitiveness and promoting equitable development among their members. Weak management skills, conflicts of interests and insufficient government or external support may be at the root of some problems.

In both cases (private large investments or producer associations) environmental sustainability is at stake. According to studies made about sustainable natural resources management, there are several ways of alleviating pressure on the Amazonian rainforest: designation of protected areas (a measure popular for rainforest distant from the agricultural frontier); development of non-timber forest products; clearer property rights to foster greater investment in sustained productivity; agricultural intensification that allows less land to be used for the same level of farm output; and improved education opportunities to divert qualified rural householders towards urban jobs, c.f. [51]. Notwithstanding the emphasis on a positive relationship between small scale exploitations and conservation, as shown by Vosti et al. in the Western Brazilian Amazon, a small-scale managed forestry strategy only postpones the conversion of virgin rainforest into agricultural land [52].

In mountain eco-regions, where population density is higher and processes of environmental deterioration (soil degradation, pastures loss, water scarcity) have already been observed, agricultural intensification has failed to occur because of households' preference to develop diversified strategies increasingly linked to urban areas or the rainforest frontier. In these eco-regions, livestock ranches (whether large or small) are damaging. By contrast, alternative crops (like coffee) seem to be more environmentally beneficial.

\subsection{Expected Impact on Welfare of Women and Gender Relationships}

According to WIDE (a women's-rights-based and social-justice-oriented network) 'gender is surprisingly invisible in mainstream discussions on economic policy on trade and on development' [53]. Main concerns about the effects of trade liberalisation in agriculture and the expansion of liquid bio-fuels production on women's welfare and gender relationships are related to the likely exacerbation of inequalities and deeper 'feminisation of poverty'. Reasons why this would happen are underpinned by men and women (as well as male-headed and female-headed households), 
their differentiated access to, and control of, the land and other productive assets, their level of participation in decision-making and socio-economic activities, unequal employment opportunities and working conditions, and differentiated effects in terms of food security [54]. Similar inequalities have been claimed in terms of the factors that induce migration. Increasing resource scarcity, higher population density and weaker migration networks are more associated with female out-migration to urban areas [55].

Given the relative novelty of the bio-fuels industry, and its correlate of lack of data to forecast any specific effect, many concerns are hypotheses based on past experience of other large-scale agricultural investments and export-led commodity growth strategies. With that background, some of the main issues raised in a scenario of bio-fuel expansion are related to its impact on women's access to, and control of, capital assets, and the conditions in which they participate in agricultural markets. Those issues are summarised in Table 6.

Table 6. Gender vulnerabilities.

\begin{tabular}{|c|c|}
\hline Category & Gender disparities \\
\hline Land ownership & $\begin{array}{l}\text { Land ownership is traditionally skewed towards men (e.g., in Brazil only } 11 \text { percent of } \\
\text { land is owned by women). }\end{array}$ \\
\hline $\begin{array}{l}\text { Access to } \\
\text { financial capital }\end{array}$ & Restricted access to credit by women due to the impossibility of using land as collateral. \\
\hline $\begin{array}{l}\text { Access and } \\
\text { protection of } \\
\text { human capital }\end{array}$ & $\begin{array}{l}\text { Women's specialised knowledge of their natural environment makes them more } \\
\text { vulnerable to potential biodiversity loss when monocultures are expanded. } \\
\text { This also produces narrower future options for economic diversification. }\end{array}$ \\
\hline $\begin{array}{l}\text { Human capital: } \\
\text { time and effort } \\
\text { management }\end{array}$ & $\begin{array}{l}\text { Women in rural areas dedicate a considerable part of their time to water and firewood } \\
\text { collection for domestic use. }\end{array}$ \\
\hline $\begin{array}{l}\text { Access to and self- } \\
\text { sufficiency of } \\
\text { physical capital }\end{array}$ & $\begin{array}{l}\text { Women have lower access to pesticides and external inputs, and, consequently, are } \\
\text { more vulnerable to market shocks (fluctuation in the price of cash crops and external } \\
\text { inputs). }\end{array}$ \\
\hline $\begin{array}{l}\text { Access to } \\
\text { employment }\end{array}$ & Women’s levels of literacy and school enrolment are lower than men's. \\
\hline Labour income & $\begin{array}{l}\text { The gender gap in earnings is particularly high in informal employment. Also, unpaid } \\
\text { work (for women and children) has been registered in cases of piece-rate employment } \\
\text { arrangements in sugar cane plantations. }\end{array}$ \\
\hline $\begin{array}{l}\text { Working } \\
\text { conditions }\end{array}$ & $\begin{array}{l}\text { Casual or temporary jobs to which women have more access usually include few-if } \\
\text { any-social benefits. Access to decent work is hard to achieve (in Latin America, } 40 \\
\text { percent of waged agricultural workers under informal labour arrangements are women). }\end{array}$ \\
\hline Food security & Female-headed households are more vulnerable to food price increases. \\
\hline
\end{tabular}

Source: Adapted from [57] and the references therein.

Despite the validity of that argument, it is also worth mentioning that a sustainable and equitable strategy of energy development has potential for significant positive impacts on women's welfare. Energy, as recently stated by the International Network on Gender and Sustainable Energy, is 'a women's business' and 'by means of better energy access and use, women can better satisfy their personal needs and collective interests' [56]. The positive effects of a pro-poor and pro-women 
energy-based development strategy can be observed, both in the domestic and the productive spheres in which rural households develop their livelihood strategies.

In the domestic sphere, greater energy development, which includes increasing access to energy sources for rural households, implies savings of labour time in women's domestic work. Widespread dependence on firewood and biomass fuels (essential for cooking) could also be reduced if other forms of fuels were made accessible to rural households, which would have positive consequences for women's and children's health.

In the remunerated-productive sphere, improvements in time use can also improve the level of women's education and their possibilities to participate in better conditions in the labour market. A similar effect is produced by improving the provision of electric energy in rural areas, which contributes to security, convenience and recreation possibilities at night. Examples of these effects can be found throughout Latin America in many rural electrification programmes.

Finally, although to date the bio-fuels industry has focused on the transport industry, its potential for substituting traditional forms of energy for other uses, notably those needed in rural areas, is vast (for instance, electric energy, cooking and refrigeration, power-driven agricultural machinery, as it has been proposed in [44]).

\section{Conclusions and Policy Implications for the EU-Mercosur TA}

The prospects of impacts of a trade liberalisation scenario between the EU and Mercosur on vulnerable groups of rural population in Mercosur countries seem likely to be mixed. The positive outcomes expected from growth in the agriculture and forestry sectors are based on the estimated new employment that new large-scale investments could produce in some regions, with potential for the development of commercial agriculture. In addition, in some regions, should local producers and state agents be able to articulate efforts to conform initiatives for collective production, potential for direct participation in new investments and larger markets could be significant. In both cases, given the trajectory of bio-fuels production in countries such as Brazil, its accumulated experience and its potential in terms of natural resources for bio-fuels feedstock, a well-planned territorial expansion might feed a virtuous pro-poor growth circle. To a lesser extent, similar effects could also be observed in Argentina and Paraguay.

The risks of negative impacts arise from structural factors that condition the access of poor rural populations - and particularly women and indigenous groups - to productive assets such as land and opportunities for labour-market-oriented education. Furthermore, if no particular attention is paid to these factors, a trade liberalisation scenario could lead to assets dispossession and further deterioration of labour standards. Indeed, as has been remarked elsewhere, the problem in most of Latin America is inequality [58]. High inequality of income distribution, and of opportunities to participate in growth processes, underpin the uneven development that can widely be observed in many Mercosur countries. The following quote about Brazil illustrates how people perceive this issue: '...participants [in the workshop] made it clear that Brazil is not a poor country but an unjust one. It has good laws and an equitable constitution but policy is diverted and fails at the implementation stage' [59].

In spite of the official discourse to tackle this problem, the linkage between micro-level livelihoods and macro-level policy-making and implementation is a weak one, and that is precisely what produces 
tension and opposition to development initiatives that bring risks of increasing inequality. Therefore, the challenge for policy makers who are negotiating the EU-Mercosur TA is twofold. Firstly, from the very beginning, they will need to produce enough signs of inclusive development that will convince disadvantaged populations - and the civil society organisations who advocate for environmental protection and people's rights, c.f. [60] - of the benefits of trade integration. Secondly, incentives to foster productive participation will have to consider particular enhancing and mitigating measures targeting specific groups (either geographically or individually) with a particular focus on women.

It would certainly be naïve and politically risky to assume that social structures can be changed by decree (that is, simple regulatory measures). Having said that, it should also be recognised that historical examples of economic integration show that trade agreements can produce structural change (economic and social), if they are accompanied by strong policies directed at fostering social cohesion. Despite all the difficulties, the EU is precisely the paramount example of those synergetic effects. Therefore, the questions are about the extent to which the Mercosur institutional structure facilitates this type of effect (that is, structural economic and social change) and how the EU-Mercosur TA overcomes the fact that Mercosur is not an economic union, but a trade union. The immediate implication of this is that negotiations are 'product-based' and not 'people-based', both between the EU and Mercosur, and within Mercosur itself.

In that sense, and considering that environmental and social sustainability is in jeopardy when the expansion of energy-driven industries (bio-fuels included) becomes aggressive, a focus on territorial planning, with a strong role played by the state at all levels, is essential. The recent ECLAC-GTZ study suggests, for example, a centralised approach to control and manage the expansion of bio-fuels production [43]. A broader coordinating regional body would be needed for the Gran Chaco [61]. Together with this, there is a need for policy measures to support national and regional economic diversification, which would open more employment opportunities to absorb excessive labour force that flows from depressed rural areas and to create the conditions for broader rural development. Examples taken from other Latin American experiences show that diversification and increased financial capital availability can provide the means for capital-led intensification, with a correlate of small farmers investing in irrigation for intensive agricultural production. As the Chilean experience shows, key factors for such a positive joint outcome of income generation and good environmental management are a state policy on irrigation and publicly subsidised credit, which favoured all farmers, and the occurrence of external positive booms which increases off-farm work opportunities for smallholders [62].

In the Brazilian case, despite the high social cost involved in the promotion of the ethanol industry as an oil substitute, the 1980-1990 decade shows that ethanol expansion has been a state strategy that involves economic criteria (the allocation of subsidies included) and also distributional objectives and pollution benefits [63]. With the drawbacks produced by the oil prices boom in the 2000s for net import countries (such as Paraguay and Uruguay), priority towards bio-fuels expansion is even more evident in a trade-union scenario. However, as has been shown for other world regions, production costs of bio-fuels and potential conflicts with food production may not make bio-ethanol a desirable oil substituent strategy for other countries (such as the other Mercosur members); for instance, Peters and Thielman [64] show that with the exception of Brazil, other countries (for instance, India and Tanzania) present higher production costs than those of fossil fuels. 
The final reflection of this paper highlights the importance of sequencing-not only in terms of tariffs reduction but also of enforcement of regulatory mechanisms - to improve the abilities of less advantaged groups to participate in trade-led processes of agricultural intensification or industrialisation. Regulations recommended to produce enhancing or mitigating measures - although sound and useful-can also produce drawbacks for a more inclusive model of a trade-based development strategy. For instance, the Mercosur Negotiations SIA states that 'there is a need for certification processes which reward products that are produced sustainably, thus creating a market for environmental quality and the welfare of production workers' (Trade SIA of Mercosur Negotiations-Revised Inception Report 2008, p. 68). No one would disagree with those suggestions. However, there is also need for a balanced view of prescriptive recommendations - desirable but not always applicable - and the market-based readjustments needed to make the application and reinforcement of that regulation sustainable. This is not to advocate for the continuation-or even strengthening - of unacceptable practices of forced and unpaid labour in commercial units of the agricultural and forestry sectors already fully integrated into markets. It is rather to acknowledge that the cultural and institutional change that assimilation and implementation of new regulation bring is something achievable in time and sustainable if - and only if - small economic units internalise the short-term costs of such regulation into their long-term prospects of growth.

The adaptation of institutions (both formal and informal) to new regulatory systems fundamentally depends on domestic governance, but it can certainly benefit from flexible regulatory agreements elaborated at international level, which would allow Mercosur countries to sequentially adapt their domestic circumstances to EU and other international standards, without threatening the potential benefits of a TA by imposing non-tariff restrictions-precisely on those who are less endowed to qualify for participating in the big international trade game: the small rural entrepreneurs.

\section{Acknowledgements}

This paper is based on a background paper prepared for the Impact Assessment Research Center (IARC), at the University of Manchester, as part of its Impact Assessment (Trade SIA) of the Association Agreement under negotiation between the European Community and Mercosur. The author is thankful to the IARC for granting permission to publish this paper, to Colin Kirkpatrick and Nicola Phillips for their comments in a previous version, and to the two anonymous reviewers whose comments are greatly appreciated

\section{References and Notes}

1. Giordano, P. The External Dimension of MERCOSUR: Prospects for North-South Integration with the European Union; Royal Institute of International Affairs, Mercosur Study Group: London, UK, 2002.

2. Trade SIA of the Association Agreement under Negotiation between the European Community and MERCOSUR. Final Overview and Sector Studies; June 2008; Available online: http://www.siatrade.org/mercosur/phase2/OVERVIEW_INCEPTION_revised_June_08.pdf (accessed February 26, 2009). 
3. Inclusive Integration for Global Competitiveness: Strengthening the EU-LAC Partnership; Inter-American Development Bank: Washington, DC, USA, 2006.

4. Trade SIA of the Association Agreement under Negotiation between the European Community and MERCOSUR; The Impact Assessment Research Centre (IARC), the University of Manchester: Manchester, UK, 2007; Available online: http://www.sia-trade.org/mercosur (accessed February 27, 2009).

5. Johnson, F.X.; Rosillo-Calle, F. Biomass, Livelihoods and International Trade; Stockholm Environment Institute: Stockholm, Sweden, 2007.

6. Bioenergy and Agriculture: Promises and Challenges; Hazell, P., Pachauri, R.K., Eds.; International Food Policy Research Institute: Washington, DC, USA, 2006.

7. Doornbosch, R.; Steenblik, R. Biofuels: Is the Cure Worse than the Disease? In Proceedings of the 20th Meeting of the Round Table on Sustainable Development, Paris, France, September 11-12, 2007.

8. SIA EU-Mercosur Final Report 2007; Available online: http://www.sia-trade.org/mercosur/ phase1/OVERALL_FINAL_REVISEDNOVEMBER.pdf (accessed February 17, 2009).

9. Hinojosa, L. Property rights and rights-based sustainable livelihoods. In Rights-Based Approaches to Development: Exploring the Potential and Piffalls; Hickey, S., Mitlin, D., Eds.; Kumarian Press: New York, NY, USA, 2009.

10. Bebbington, A.; Rojas, R.; Hinojosa, L.; Muñoz, D.; Cuerrero, E.; Martinez, E. Contributions of the Dutch Co-Financing Program to Rural Development and Rural Livelihoods in the Highlands of Peru and Bolivia. Synthesis Report. Study Commissioned by the Steering Committee for the Evaluation of the Netherlands' Co-financing Programme: Boulder, CO, USA, 2002.

11. APRODEV. http://www.aprodev.net (accessed February 17, 2009).

12. McCulloch, N.; Winters, L.A.; Cirera, X. Trade Liberalization and Poverty: A Handbook; Centre for Economic Policy Research: London, UK, 2001.

13. Harvey, D. The new imperialism: on spatio-temporal fixes and accumulation by dispossession. The Socialist Register 2004, 40, 63-87.

14. IFAD. http://www.ruralpovertyportal.org/english/regions/americas/bra/index.htm (accessed February 27, 2009).

15. FAO, Brazil, Country Profile. http://www.fao.org/ag/AGP/AGPC/doc/Counprof/Brazil.htm\#1 (accessed February 17, 2009).

16. FAO. http://www.fao.org/ag/AGP/AGPC/doc/Counprof/Brazil.htm\#5.\%20THE\%20PASTURE (accessed February 27 2009).

17. Paraguay: A Country Study; Hanratty, D.M., Meditz, S., Eds.; GPO for the Library of Congress: Washington, DC, USA, 1988.

18. FAO. http://www.fao.org/ag/AGP/AGPC/doc/Counprof/uruguay/uruguay.htm (accessed February 17, 2009).

19. FAO. http://www.fao.org/ag/AGP/AGPC/doc/Counprof/Venezuela/venezuela.htm (accessed February 27, 2009).

20. FAO. http://www.fao.org/ag/AGP/AGPC/doc/Counprof/Argentina/argentina.htm (accessed February 17, 2009). 
21. SIA of Mercosur Negotiations-Forestry Sector Study; Available online: http://www.sia-trade.org/mercosur/phase1/forestryfinalrevisedFebruary08.pdf (accessed February 17, 2009).

22. Goldenberg, J.; Teixeira Coelho, S.; Guardabassi, P. The sustainability of ethanol production from sugarcane. Energ. Policy 2008, 36, 2086-2097.

23. IPS. http://www.ips.org (accessed February 17, 2009).

24. Myers, N. Tropical forest: the main deforestation fronts. Environ. Conserv. 1993, 20, 9-16.

25. Kaimowitz, D.; Smith, J. Soybean technology and the loss of natural vegetation in Brazil and Bolivia. In Agricultural Technologies and Tropical Deforestation; Angelsen, A., Kaimowitz, D., Eds.; CABI Publishing: Wallingford, UK, 2001; pp. 195-211.

26. Schmink, M.; Wood, C.H. Contested Frontiers in Amazonia; Columbia University: New York, NY, USA, 1992.

27. Simmons, C.; Perz, S.; Pedlowski, M.; Teixeira Silva, L. The changing dynamics of land conflict in the Brazilian Amazon: The rural-urban complex and its environmental implications. Urban Ecosystems 2002, 6, 99-121.

28. Carr, D.L.; Norman E. Global civil society? The Johannesburg World Summit on sustainable development. Geoforum 2008, 29, 358-371.

29. Lipschutz, R. Crossing borders: global civil society and the reconfiguration of transnational Political Space. GeoJournal 2000, 52, 1, 17-23.

30. SIA of EU-Mercosur Trade Negotiations-Overall Preliminary SIA. Comments and ResponsesPublic Consultation. Available online: http://www.sia-trade.org/mercosur/consultation/ (accessed February 17, 2009).

31. Berdegue, J.A.; Ramirez, E.; Reardon, T.; Escobar, G. Rural nonfarm employment and incomes in Chile. World Develop. 2001, 29, 411-425.

32. Bebbington, A. Livelihood transitions, place transformations: grounding globalization and modernity. In Latin America Transformed: Globalization and Modernity; Gwynne, R., Kay, C., Eds.; Edward Arnold: London, UK, 2004; pp. 173-192.

33. Hinojosa, L. Institutions, Markets and Economic Development in the Southern Peruvian Andes. $\mathrm{PhD}$ thesis, University of Manchester, 2006.

34. Rodriguez, J. Spatial Distribution of the Population, Internal Migration and Development in Latin America and The Caribbean; United Nations Expert Group on Population Distribution, Urbanization, Internal Migration and Development: New York, NY, USA, 2008.

35. Carr, D. Population and deforestation: why rural migration matters. Progr. Hum. Geogr. 2009, 33, 355-378.

36. Cerruti, M.; Bertoncello, R. Urbanization and Internal Migration Patterns in Latin America; Buenos Aires: Centro de Estudios de Población, Argentina, 2003.

37. Vapñarsky, C. Primacia y macrocefalia en la Argentina: La tranformación del sistema de asentamiento humano desde 1950. Desarrollo Economico 1995, 35, 227-254.

38. Fiess, N.; Verner, D. Migration and human capital in Brazil in the 1990s. In World Bank Policy Research Working Paper Series 3093; World Bank: Washington, DC, USA, 2003.

39. ITUC. http://survey07.ituc-csi.org/getcountry.php?IDCountry=BRA\&IDLang=EN (accessed February 27, 2009). 
40. Jepson, W. Private agricultural colonization on a Brazilian frontier, 1970-1980. J. Hist. Geogr. 2006, 32, 839-863.

41. ITUC. http://www.ituc-csi.org/spip.php?rubrique9 (accessed February 27, 2009).

42. Lawrence, R.; Paredes, M.; Fluckiger, Y.; Lambert, C.; Werna, E. Promoting decent work in the construction sector: The role of local authorities. Habitat Int. 2008, 32, 160-171.

43. ECLAC and GTZ 2008. Available online: http://www.gtz-cepal.cl (accessed February 17, 2009).

44. Sustainable Bioenergy: A Framework for Decision Makers. United Nations, New York, NY, USA, 2007; Available online: http://esa.un.org/un-energy/pdf/susdev.Biofuels.FAO.pdf (accessed February 26, 2009).

45. Lawson, V. Hierarchical households and gendered migration in Latin America: feminist extensions to migration research. Progr. Hum. Geogr. 1998, 22, 39-53.

46. Foweraker, J. The Struggle for Land: A Political Economy of the Pioneer Frontier in Brazil, 1930 to Present. Cambridge University: Cambridge, UK, 1981.

47. Wood, C.H. Peasant and capitalist production in the Brazilian Amazon: A conceptual framework for the study of frontier expansion. In The Dilemma of Amazonian Development; Moran, E., Ed.; Westview Press: Boulder, CO, USA, 1983, pp. 259-277.

48. Walker, R.T.; Homma, A.K.O. Land use and land cover dynamics in the Brazilian Amazon: an overview. Ecol. Econ. 1996, 18, 67-80.

49. ACDIVOCA. http://www.acdivoca.org (accessed February 17, 2009).

50. Tierramerica. http://www.tierramerica.info (accessed: February 17, 2009).

51. Scott, S.; Escobar, G.; Reardon, T. Poverty and environment in Latin America: concepts, evidence and policy implications. World Develop. 2003, 31, 1865-1872.

52. Vosti, S.A.; Muñoz, E.B.; Line Carpentier, C.; d'Oliveira, M.; Witcover, J. Rights to forest products, deforestation and smallholder income: evidence from the Western Brazilian Amazon. World Develop. 2003, 31, 1889-1901.

53. EU Bilateral and Regional Free Trade Agreements: Bringing Women to the Centre of the Debate; Thompson, M., Ed.; WIDE: Brussels, Belgium, 2007; Available online: http://62.149.193.10/ wide/download/WIDEEUBILATERAL.pdf?id=594 (accessed February 26, 2009).

54. UN Agency Women Watch. http://www.un.org/womenwatch (accessed February 17, 2009).

55. Barbieri, A.; Carr, D. Gender-specific out-migration, deforestation and urbanisation in the Ecuadorian Amazon. Global Planet. Change 2005, 47, 99-110.

56. Where Energy Is Women's Business: National and Regional Reports from Africa, Asia, Latin America and the Pacific; Karlsson, G., Ed.; ENERGIA: Leusden, The Netherlands, 2007.

57. Rossi, A.; Lambrou, Y. Gender and Equity Issues in Liquid Biofuels Production; FAO: Rome, Italy, 2008.

58. World Development Report 2006: Equity and Development; World Bank: Washington, DC, USA, 2006.

59. Marzetti, G. Natural Resources. DFID: Brasilia, Brazil, 2001; unpublished report.

60. CBD Alliance. Call to the UN to Stop Biofuels Expansion; EFE: Madrid, Spain, 19 May 2008.

61. Bucher, E.H.; Huszar, P.C. Sustainable management of the Gran Chaco of South America: Ecological promise and economic constraints. J. Environ. Manage. 1999, 57, 99-108. 
62. Bahamondes, M. Poverty-environment patterns in a growing economy: farming communities in arid Central Chile, 1991-99. World Develop. 2003, 31, 1947-1957.

63. Rask, K. The social costs of ethanol production in Brazil: 1978-1987. Econ. Develop. Cult. Change 1995, 43, 627-649.

64. Peters, J.; Thielmann, S. Promoting bio-fuels: Implications for developing countries. Energ. Policy 2008, 36, 1538-1544.

65. Pistonesi, H.; Nadal, G.; Bravo, V.; Bouille, D. Aporte de los biocombustibles a la sustentabilidad del desarrollo en América Latina y el Caribe: Elementos para la formulación de políticas públicas; ECLAC and GTZ: Santiago de Chile, Chile, 2008.

66. World Bank. World Development Indicators November 2007; ESDS International, (Mimas), University of Manchester: Manchester, UK, 2007.

67. Gray, C.L. Environment, land and rural out-migration in the Southern Ecuadorian Andes. World Develop. 2009, 37, 457-468.

(C) 2009 by the authors; licensee Molecular Diversity Preservation International, Basel, Switzerland. This article is an open-access article distributed under the terms and conditions of the Creative Commons Attribution license (http://creativecommons.org/licenses/by/3.0/). 